\title{
X-linked intellectual disability, Turner type
}

INSERM

\section{Source}

INSERM. (1999). Orphanet: an online rare disease and orphan drug data base. $\underline{X \text {-linked }}$ intellectual disability, Turner type. ORPHA:85328

X-linked intellectual disability, Turner type is characterised by moderate to severe intellectual deficit in boys and moderate intellectual deficit in girls. It has been described in 14 members from four generations of one family. Macrocephaly was reported and holoprosencephaly may also be present (two family members). The mode of transmission is X-linked semi-dominant. 